\title{
Susceptibility of different tomato, Solanum lycopersicum L., varieties to infestation with some insect pests in Egypt
}

\author{
Youssef Ahmed Mahmoud ${ }^{1 *}$, Ibrahim Mohamed Abd El-Monem Ebadah', Wedad Attwa², Sayed Moawad', \\ Neama Omar ${ }^{2}$, Tarek Essa Abd El-Wahab ${ }^{1}$ and Hanaa Sadek ${ }^{1}$
}

\begin{abstract}
Background: Tomato, Solanum lycopersicum L (=Lycopersicon esculentum Miller), is one of the most economically important crops in the world. In Egypt, tomato is infested with different pests causing damages in both quantity and quality of the yields. Six varieties of tomato, 'Strain B,' 'Beto', 'El bandora,' 'GS,' 'Casterlok,' and 'Super strain B', were evaluated for their susceptibility to some insect pest infestations during summer plantation under field conditions.
\end{abstract}

Results: According to the infestation with Tuta absoluta, the highly susceptible varieties that received the highest number of eggs were El bandora, followed by Strain B, while Super strain was the lowest. The obtained results indicated that the tomato Super strain B variety had much tolerance to the infestation by T. absoluta. GS variety recorded the highest mean number of eggs deposited by Phthorimaea operculella, but no eggs were observed on the leaves of El bandora and Super strain B varieties. Results also indicated that mean number of Liriomyza trifolii larvae/20 leaflets was the highest in Strain B and GS varieties. Strain B variety recorded the highest mean number of Bemisia tabaci eggs and nymphs/20leaflets than GS, which recorded the lowest value. Casterlok variety had the lowest mean number of Aphis gossypii, while, Super strain B and Strain B recorded the highest values.

Conclusions: Generally, all the six tested varieties were susceptible to infestation with several insect pests. The most susceptible variety was Strain B, followed by El bandora and GS while the lowest ones were the varieties Beto 86 and Super strain B.

Keywords: Tomato varieties, Insect pests' infestation, Susceptibility, Summer plantation

\section{Background}

Tomato, Solanum lycopersicum L. (=Lycopersicon esculentum Miller) (Solanaceae), is one of the most economically important crops in the world. Many insect species are reported to attack tomatoes worldwide, which cause considerable damage to both quantity and quality of the fruits (Faragalla 2005). These pests cause damages to the yield quantity and quality (Žnidarčič et al. 2003). Some of these insect species are known to be of great

\footnotetext{
* Correspondence: youssefmahamoud@yahoo.com

1 Department of Pests and Plant Protection, National Research Centre,

El-Behoose St., Dokki, P.O.Box 12622, Cairo, Egypt

Full list of author information is available at the end of the article
}

economic importance, such as the tomato leaf miner, Tuta absoluta (Meyrick), (Lepidoptera: Gelechiidae) (Mohamed 2010; Bekheit and Impiglia 2011; Khidr et al. 2013; Mahmoud et al. 2015; Tayeb et al. 2018), the potato tuber moth, Phthorimaea operculella Zeller (Lepidoptera: Gelechiidae) where the larvae penetrate the tomato fruit through the stem end and present a serious threat to crop quality (Filgueira 2003), the American serpentine leafminer, Liriomyza trifolii (Burgess) (Diptera: Agromyzidae) where both larvae and adults cause damage: larvae primarily mine the palisade mesophyll and adult females tunnel puncture both upper and lower leaf surfaces to feed and lay eggs. The feeding of the 
leafminers can drastically reduce the photosynthesis and respiration consequently affecting crop production (Leibee 1984), and the tobacco whitefly, Bemisia tabaci (Genn.) (Hemiptera: Aleyrodidae) is a pest that causes direct damage by feeding on the phloem sap and it produces honeydew on which sooty molds can grow (Nomikou et al. 2004). This may result in physiological disorders of the plant, such as leaf wilting and irregular ripening of the fruit. However, the main problem caused by $B$. tabaci is the damage done by the viruses they transmit (McCollum et al. 2004). Also, tomato plants are attacked by the cotton aphid, Aphis gossypii (Glover), Hemiptera: Aphididae) (Fargalla 2005), which causes indirect damage by transmitting several microorganisms such as viral and fungal diseases from infected to healthy plants. (Abd-El-wahab et al. 1996; Saethre et al. 2011).

The objective of this study was to determine the susceptibility of six common tomato varieties/strains in Egypt to infestation with some insect pests under the field and laboratory conditions.

\section{Materials and methods}

Field experiment

The present study was carried out at the southern region of Assiut Governorate (Dairut District), Egypt, in the summer season (summer plantation) of tomato to evaluate the infestation of different tomato varieties with some insect pests.

An area of about $240 \mathrm{~m}^{2}$ (divided into 18 blocks (of about $12 \mathrm{~m}^{2}$ /block) was cultivated with the 6 tomato varieties (Strain B, Beto 86, El bandora, GS, Casterlok, and Super strain B). Every block was separated from the other by uncultivated two rows. The seeds were obtained from the Ministry of Agriculture, Egypt, and seedlings were transplanted on the first week of February, 2013 as summer plantation. Three replicates of each variety were transplanted and evaluated in complete randomized design. All regular recommended agricultural practices were followed without any pesticide treatments during the whole period of the experiment. Sampling started 15 days post-planting, whereas 20 leaves from each replicate were collected at weekly interval up to the end of the season (23 June). The leaves were picked manually, placed in paper bags, and transferred to the laboratory for examination under a stereomicroscope to determine the number of tunnels, larvae, and eggs/leaflets, and the number of immature stages/leaf of the tested plants (Rabie 2014).

\section{Laboratory experiments}

\section{Susceptibility of the tomato varieties to infestation with} Tuta absoluta

Two methods were applied for evaluating the susceptibility of the six tomato varieties to the infestation by $T$. absoluta according to external (epiphylaxis) and internal (endophylaxis) factors.

In order to determine the ovipositional preference of the tomato leafminer to different tomato varieties, the following experiments were conducted

\section{Epiphylaxis factors}

Multiple choice test An experiment was carried out in a cage $(30 \times 30 \times 60 \mathrm{~cm})$ under the laboratory conditions of $\left(26 \pm 2{ }^{\circ} \mathrm{C}\right.$ and $\left.65 \pm 5 \% \mathrm{RH}\right)$. Twelve pots of tomato ( 2 pots/variety) were arranged inside the experimental cage. Thirty pairs of virgin females and males of T. absoluta were introduced into a cage, which contained one pot from each tested tomato variety arranged in a circle inside the cage. Each test was replicated five times. After 8 days, the numbers of deposited eggs on the plant of each pot variety was counted in order to determine the susceptibility of different tomato varieties to tomato leafminer infestation.

No-choice test Each variety was also tested under a non-choice experiment for comparison by placing 3-4 leaves of each tested tomato variety in a separate Petri dish $(10 \mathrm{~cm}$ in dia. containing a thin layer of moist cotton), and then one pair of virgin female and male of $T$. absoluta was released into the Petri dish. Experiments were carried out under the laboratory conditions. After 5 days, number of deposited eggs/female was counted and compared with those on other varieties.

\section{Endophylaxis factors}

This experiment was conducted according to the method of Rabei (2014) to study the feeding preference of neonate larvae of $T$. absoluta toward the tested tomato varieties; this experiment was conducted in Petri dishes (10 cm in dia.) with one leaflet of each variety was separately placed inside a Petri dish and five neonate larvae were placed on the leaflets. After 5 days, the percentage of penetrating larvae was estimated according to the following equation:

Penetrating larvae $\%=(Y / X) \times 100$

Where $X$ is total number of tested neonate larvae $Y$ is the number of larvae inside tested variety. Mean duration of larval stage was calculated.

\section{Statistical analysis}

The data were subjected to analysis of variance (ANOVA) through SPSS computer program and significant differences among means of different varieties were separated using the least significant difference (LSD at $5 \%)$ 


\section{Results}

\section{Field experiment}

The leaf miners (T. absoluta), (Ph. operculella), and (L. trifolii); cotton aphid (A. gossypii); and tobacco whitefly (B. tabaci) were the target insect pests in the field study.

\section{Infestation with T. absoluta, Ph. operculella, and L. trifolii} Insignificant differences $(p>0.05)$ were found among the tested varieties of tomato plants to the infestation (mean number of tunnels, larvae, and eggs/leaflets) with T. absoluta, Ph. operculella, and L. trifolii during the study period (Table 1). According to the infestation by T. absoluta, the highly susceptible varieties, based on the highest number of eggs was in El bandora variety (1.13 \pm $0.2)$, followed by Strain B $(0.93 \pm 0.2)$, while Super strain $B$ recorded the lowest value $(0.5 \pm 0.2)$. Mean number of tunnels/leaflet reached the highest number $(3.0 \pm 0.41)$ in GS variety than the other tested varieties, while Super strain $B$ variety recorded the lowest number $(1.8 \pm 0.2)$. The mean number of larvae/20 leaflets reached the maximum in the most tested varieties, but the lowest number was recorded in Super strain B $(0.26 \pm 0.1)$. The results indicated that the tomato Super strain B had more tolerance to the infestation with $T$. absoluta.

Regarding the Ph. operculella infestation, significant differences were recorded among the tested varieties in the number of eggs/leaflet. GS variety recorded the highest number $(19 \pm 0.53)$ deposited by Ph. Operculella, but no eggs were found on the leaves of El bandora and Super strain B.

With regard to L. trifolii infestation, El bandora variety had the highest number of tunnels/leaflet $(18.0 \pm 2.15)$, followed by Strain B $(17.6 \pm 2.3)$ and Casterlok (15.3 \pm 2.27), while Super strain B had the lowest number of tunnels $(12.4 \pm 2.35)$. Results also indicated that mean number of larvae/leaflet was the highest in case of Strain
B (10.8 \pm 0.16$)$ and GS varieties $(10 \pm 1.3)$, but had the lowest value $(6.3 \pm 1.5)$ for the Beto 86 variety.

Susceptibility data of the tested tomato varieties to infestation with $B$. tabaci was represented in Table 2. The data showed that there were insignificant differences in the mean numbers of eggs and nymphs/leaflet among the tomato varieties. Strain B variety recorded the highest mean number of eggs $(24.42 \pm 3.68)$ and nymphs $(34.2 \pm 6.8) /$ leaflet in comparison with GS, which recorded the lowest values $(19.8 \pm 3.21$ and $19.5 \pm 3.2$ for eggs and nymphs, respectively).

\section{Infestation with A. gossypii}

Regarding the infestation with $A$. gossypii, the results are summarized in Table 2 indicating that significant differences were found in the mean number of immature stages/leaflet among the tested tomato varieties. Casterlok variety had the lowest mean number of immature stages (2.6/leaflet), while the Super strain B and Strain B recorded the highest values (5.7 and 9.8/leaflet, respectively).

\section{Laboratory experiments \\ Epiphylaxis factors (ovipositional pereference for $T$. absoluta)}

The data presented in Table 3 show the role of the nature, external feel and external structures of the leaves of different tomato varieties in the selection of T. absoluta to the site of oviposition. The data of choice and nochoice tests showed that there were insignificant differences $(p>0.05)$ among the six varieties according to the number of eggs deposited on each variety.

\section{Endophylaxis factors}

To evaluate the susceptibility of six tomato cultivars according to endophylaxis factors, the feeding preference of the tomato leafminer was determined through the following points.

Table 1 Susceptibility of different tomato varieties to infestation with some insect pests during summer plantation (2013) at Assiut Governorate

\begin{tabular}{|c|c|c|c|c|c|c|c|c|c|}
\hline \multirow[t]{2}{*}{$\begin{array}{l}\text { Tomato } \\
\text { varieties }\end{array}$} & \multicolumn{3}{|c|}{$\begin{array}{l}\text { Tuta absoluta } \\
\text { Mean no./20 leaflets ( } \pm \text { SE) }\end{array}$} & \multicolumn{3}{|c|}{$\begin{array}{l}\text { Phthorimaea operculella } \\
\text { Mean no./20 leaflets }( \pm \text { SE) }\end{array}$} & \multicolumn{3}{|c|}{$\begin{array}{l}\text { Liriomyza trifolii } \\
\text { Mean no./20 leaflets }( \pm S E)\end{array}$} \\
\hline & Tunnels & Eggs & Larvae & Tunnels & Eggs & Larvae & Tunnels & Eggs & Larvae \\
\hline Strain B & $2.0 \pm 0.3 a b$ & $0.93 \pm 0.24 a$ & $0.93 \pm 0.2 a$ & $0.8 \pm 0.17 a$ & $0.46 \pm 0.1 \mathrm{ab}$ & $0.6 \pm 0.13 a$ & $17.6 \pm 2.3 a$ & $\mathrm{~N} / \mathrm{I}$ & $10.8 \pm 0.1 a$ \\
\hline Beto 86 & $2.26 \pm 0.2 \mathrm{ab}$ & $0.73 \pm 0.28 a$ & $0.73 \pm 0.2 a$ & $0.8 \pm 0.2 \mathrm{a}$ & $0.33 \pm 0.1 \mathrm{ab}$ & $0.4 \pm 0.16 a$ & $14.0 \pm 2.0 a$ & $\mathrm{~N} / \mathrm{I}$ & $8.1 \pm 1.8 a$ \\
\hline El bandora & $2.8 \pm 0.43 a b$ & $1.13 \pm 0.25 a$ & $0.93 \pm 0.2 a$ & $0.4 \pm 0.16 a$ & $0.00 c$ & $0.3 \pm 0.15 a$ & $18.0 \pm 2.1 a$ & $\mathrm{~N} / \mathrm{I}$ & $10.8 \pm 0.16 a$ \\
\hline GS & $3.0 \pm 0.41 a$ & $0.6 \pm 0.21 a$ & $0.93 \pm 0.2 a$ & $0.6 \pm 0.21 a$ & $0.53 \pm 0.1 a$ & $0.2 \pm 0.11$ & $15.2 \pm 2.1 a$ & $\mathrm{~N} / \mathrm{I}$ & $8.4 \pm 1.5 a$ \\
\hline Casterlok & $2.2 \pm 0.4 a b$ & $0.8 \pm 0.21 a$ & $0.66 \pm 0.1 a$ & $0.8 \pm 0.17 a$ & $0.13 \pm 0.0 b c$ & $0.2 \pm 0.15 a$ & $15.3 \pm 2.2 \mathrm{a}$ & $\mathrm{N} / \mathrm{I}$ & $9.7 \pm 0.9 a$ \\
\hline $\begin{array}{l}\text { Super } \\
\text { strain B }\end{array}$ & $1.8 \pm 0.2 b$ & $0.5 \pm 0.2 a$ & $0.26 \pm 0.1 a$ & $0.4 \pm 0.1 a$ & $0.00 \mathrm{c}$ & $0.5 \pm 0.19 a$ & $12.4 \pm 2.3 a$ & $\mathrm{~N} / \mathrm{I}$ & $6.3 \pm 1.5 a$ \\
\hline$F$ & $1.91^{\mathrm{ns}}$ & $0.84^{\mathrm{ns}}$ & $1.26^{\mathrm{ns}}$ & $0.98^{\mathrm{ns}}$ & 3.7 & $0.81^{\mathrm{ns}}$ & $0.89^{\text {ns }}$ & & $1.27^{\mathrm{ns}}$ \\
\hline
\end{tabular}

Means in rows with the same letters are not significantly different $(p \geq 0.05)$ 
Table 2 Susceptibility of different tomato varieties to infestation with Bemisia tabaci and Aphis gossypii during summer plantation 2013 at Assiut Governorate

\begin{tabular}{|c|c|c|c|}
\hline \multirow[t]{2}{*}{$\begin{array}{l}\text { Tomato } \\
\text { varieties }\end{array}$} & \multicolumn{2}{|c|}{$\begin{array}{l}\text { Bemisia tabaci } \\
\text { Mean no./20 leaflets } \\
( \pm \text { SE })\end{array}$} & \multirow{2}{*}{$\begin{array}{l}\text { Aphis gossypii } \\
\text { Mean no./20 leaflets } \\
( \pm \text { SE) } \\
\text { Nymphs }\end{array}$} \\
\hline & Eggs & Nymphs & \\
\hline Strain B & $24.2 \pm 3.68 a$ & $34.2 \pm 6.8 \mathrm{a}$ & $9.8 \pm 2.5 a$ \\
\hline Beto 86 & $21.9 \pm 4.95 a$ & $22.3 \pm 4.4 a$ & $2.7 \pm 0.5 b$ \\
\hline El bandora & $21.3 \pm 3.67 a$ & $25.2 \pm 5.7 a$ & $2.8 \pm 0.5 b$ \\
\hline G.S & $19.8 \pm 3.21 a$ & $19.5 \pm 3.2 \mathrm{a}$ & $8.7 \pm 2.2 \mathrm{a}$ \\
\hline Casterlok & $24.0 \pm 4.87 a$ & $29.0 \pm 6.09 a$ & $2.6 \pm 0.6 b$ \\
\hline $\begin{array}{l}\text { Super } \\
\text { strain B }\end{array}$ & $21.0 \pm 3.4 a$ & $25.0 \pm 5.9 a$ & $5.7 \pm 2.1 \mathrm{ab}$ \\
\hline$F$ & $0.17^{\mathrm{n} . \mathrm{s}}$ & $0.87^{\mathrm{n} . \mathrm{s}}$ & 3.63 \\
\hline
\end{tabular}

Means in rows with the same letters are not significantly different $(p \geq 0.05)$ ns not significant

\section{Penetration and survival of larvae inside leaflets}

The results (Table 4) indicated that the highest number of surviving larvae (88\%) was recorded inside the leaflets of Super strain B. The other varieties were arranged in a descending order as follows: El bandora $>$ GS > Strain B > Beto 86 > Casterlok ; being 86, 86, 76, 76, and 74\%, respectively.

\section{Larval duration inside the leaf}

Table 4 showed that the duration of the larval stage inside tomato leaflets were not significantly different among the six varieties.

\section{Discussion}

Our results showed that all the tested six varieties are susceptible to infestation by $T$. absoluta, Ph. operculella, L. trifolli, B. tabaci, and A. gossypii. Bogorni et al. (2003) and Oliveira et al. (2009) studied the susceptibility of some tomato strains to infestation with T. absoluta and showed that no tomato cultivars were entirely resistant

Table 3 Ovipositional preference of the tomato leaf miner, $T$. absoluta, on six tomato varieties

\begin{tabular}{lll}
\hline $\begin{array}{l}\text { Tomato } \\
\text { varieties }\end{array}$ & $\begin{array}{l}\text { No. of deposited eggs/female } \\
\text { (mean } \pm \text { SE) }\end{array}$ & No-choice test \\
\cline { 2 - 3 } Choice test & $47.0 \pm 2.90^{\mathrm{a}}$ \\
\hline Strain B & $6.17 \pm 1.31^{\mathrm{a}}$ & $51.8 \pm 4.80^{\mathrm{a}}$ \\
Beto 86 & $4.9 \pm 0.66^{\mathrm{a}}$ & $45.4 \pm 4.00^{\mathrm{a}}$ \\
El bandora & $8.05 \pm 1.23^{\mathrm{a}}$ & $48.2 \pm 1.8^{\mathrm{a}}$ \\
GS & $6.0 \pm 1.26^{\mathrm{a}}$ & $50.0 \pm 2.26^{\mathrm{a}}$ \\
Casterlok & $6.5 \pm 0.93^{\mathrm{a}}$ & $49.0 \pm 1.25^{\mathrm{a}}$ \\
Super strain B & $8.0 \pm 0.70^{\mathrm{a}}$ & 0.69 \\
F & 1.35 & \\
\hline
\end{tabular}

Means in rows with the same letters are not significantly different $(p \geq 0.05)$
Table 4 Feeding preference and larval duration of the tomato leafminer, T. absolution, in six tomato varieties

\begin{tabular}{lll}
\hline Tomato varieties & \% Survived larvae & $\begin{array}{l}\text { Larval stage duration } \\
\text { (days) }(\mathrm{M} \pm \mathrm{SE})\end{array}$ \\
\hline Strain B & 76 & $13.8 \pm 0.20 \mathrm{a}$ \\
Beto 86 & 76 & $14.2 \pm 0.20 \mathrm{a}$ \\
El bandora & 86 & $13.8 \pm 0.20 \mathrm{a}$ \\
GS & 86 & $13.7 \pm 0.20 \mathrm{a}$ \\
Casterlok & 74 & $14.1 \pm 0.19 \mathrm{a}$ \\
Super strain B & 88 & $14.0 \pm 0.20 \mathrm{a}$ \\
F & - & 0.8 \\
\hline Means in rows with the same letters are not significantly different $(p \geq 0.05)$
\end{tabular}

to T. absoluta, but not all cultivars were equally susceptible. Gharekhani and Salek-Ebrahimi (2014) evaluated the damage of $T$. absoluta on 11 tomato cultivars and reported that damaged leaves, active mines, and damaged terminal buds were significantly different among the tomato cultivars. Ibrahim (2015) evaluated the susceptibility of different strains of tomato to this pest during the early summer and Nile rotations in 2012 and also during summer and winter rotations in 2013. It appears that the native strain was more susceptible to infestation, compared to GS and super hybrid strains in the early summer rotation of 2012. In the Nile rotation, the strain 77' was more susceptible to infestation than the strain 010,' where the number of eggs, larvae and mines on the leaves of the strain 77 were significantly higher than the strain 010 . In the summer rotation of 2013, the strain 2243'was more susceptible to infestation with T. absoluta than GS. On the other hand, the strain coded 5656' showed to be more susceptible to infestation than the strain 010, judged from the number of eggs, larvae and mines (tunnels) recorded during this season on the leaves of this strain. These findings clearly indicate the variations in the susceptibility of the most dominant tomato strains to infestation with different insect pests in Egypt. Also, the data indicated that the susceptibility level of all tested varieties to infestation by $L$. triffolli and $B$.tabaci was identically the same. In this respect, the susceptibility of 24 bean, Vicia faba L. cultivars to whitefly $B$. tabaci, with special reference to yield and pad characteristics was studied by Faris et al. (1991), they stated that the cultivars of bean revealed clear differences in their susceptibility to infestation with $B$. tabaci, these differences may be attributed to the leaf thickness and the characters of each bean variety and to the quantity and quality of the sap occupied in each one. The results about A. gossypii indicated that all tested tomato varieties were more or less attacked by aphids. Casterlok variety was less infested while Strain B variety recorded the highest infestation with aphids. This pest causes indirect damage to tomato plant by transmitting several microorganisms such as viral and fungal diseases from infected to healthy plants (Abd El- 
Wahab et al., 1996; Saethre et al. 2011). Prabhakar and Roy (2010) carried out an extensive survey of vegetable crops in different regions of North-east Bihar to record the taxonomic diversity of aphids during the period 2005-2008. They found that 17 species of aphids infesting more than 40 species of vegetable plants including tomato. In Pakistan, Ghulam (2016) recorded that the highest population mean of Whitefly Bemisia tabaci, followed by Aphid; Aphis gossipii (Glover) were found infesting the tomato crop. Their overall maximum population mean on Hybrid-1000 variety was from 4.45 to 3.02, while on Zatooni variety was from 5.30 to 4.28 , Moon Star variety was from 5.18 to 3.91 . Dekebo et al. (2019) stated that Phthorimaea operculella larvae accepted all tested tomato plant leaves and developed into adults. Larval development was fastest on the Ailsa Craig variety. Pupae developed fastest on the Moneymaker variety and slowest on LA3475.

\section{Conclusion}

The results of this research indicated that all six tested tomato varieties were susceptible to infestation with all tested insect pests, but it differed among varieties. The most susceptible variety to all the previous pests was Strain B, followed by El bandora and GS, while the Beto 86 and Super strain B showed the lowest infestation. Therefore, among all tested tomato varieties, Beto 86 is the most recommended variety for field production.

\section{Abbreviations \\ T. absoluta: Tuta absoluta; Ph. operculella: Phthoremia operculella; L. triffolli: Liriomyza trifolii; A. gossypii: Aphis gossypii}

\section{Acknowledgements}

All authors are very grateful to Prof. Stanislav Trdan, Department of Agronomy, Biotechnical Faculty, University of Ljubljana, Slovenia, for editing the language of this manuscript. Many thanks to the Department of Pests and Plant Protection and National Research Centre for the experimental facilities during this work.

\section{Authors' contributions}

This work was carried out in collaboration between all authors. Authors YAM, SM, and IMAE designed the study, performed the statistical analysis, wrote the protocol, and wrote the first draft of the manuscript. Authors WA and NO managed the analyses of the study. Author TEA and author HS managed the literature searches. All authors read and approved the final manuscript.

\section{Funding}

Not applicable

\section{Availability of data and materials}

All dataset on which abstracted of the study have been drawn are presented in the manuscript. All tables have not been published anywhere else before. All data and materials are available.

\section{Ethics approval and consent to participate}

The manuscript does not contain studies involving human participants, human data, or human tissue.

\section{Consent for publication}

Not applicable

\section{Competing interests}

All authors declare that they have no competing interest.

\section{Author details}

${ }^{1}$ Department of Pests and Plant Protection, National Research Centre, El-Behoose St., Dokki, P.O.Box 12622, Cairo, Egypt. ${ }^{2}$ Department of Zoology, Faculty of Science, Al-Azhar University, El-Nasr Road, Nasr City, P.O. Box 11751, Cairo, Egypt.

Received: 30 May 2019 Accepted: 12 March 2020

Published online: 03 April 2020

\section{References}

Abd El-Wahab H, Dawood MZ, Al-Adl EE, Hayder MF (1996) Population density of whitefly, Bemisia tabaci (Gennadius) in tomato fields and its relationship to the tomato yellow leaf curl virus diseases.J. Agric. Sc., Mansoura Univ. 10: 3546.

Bekheit HKM, Impiglia A (2011) Tuta absoluta(Tomato borer) outbreak and control measures in Egypt. EPPO/IOBC/FAO/NEPPO Joint International Symposium on management of Tuta absoluta (Tomato borer), Nov. 16-18:69.

Bogorni PC, daSilva RA, Carvelho SG (2003) Leaf mesophyll consumption by Tuta absoluta (Meyrick, 1971) (Lepidoptera: Gelechiidae) in three cultivars of Lycopersicon esculentum MILL. Ciencia Rural 33:711

Dekebo A, Aryal S, Jung C (2019) Suitability of tomato leaves for larval development of Potato Tuber Moth, Phthorimaea operculella (Zeller) (Lepidoptera: Gelechiidae). Entomological Research. https://doi.org/10.1111/ 1748-5967.12360

Fargalla FHH (2005) New Approach for controlling some pests Cucurbitaceae. M. Sc. Thesis, Fac. Sci., Mansoura Univ, Egypt.155p.

Filgueira FAR (2003) Solanáceas: agrotecnologia moderna naprodução de tomate, batata, pimentão, pimenta, berinjela e jiló.Lavras, Editora UFLA 333p.

Ghulam A (2016) Varietal Preference of Insect Pests on Tomato Crop in District Naseerabad Balochistan Pakistan. JEZS 4(4):328-330

Ibrahim ES (2015) Ecological and biological studies on Tuta absoluta (Lepidoptera: Gelechiidae) and potency of some microbial insecticides in its control. Ph.D Thesis, Fac. Sci., Al-Azhar Univ., Egypt 205 p.

Khidr AA, Gaffar SA, Maha SN, Taman AA, Fathia AS (2013) New approaches for controlling leafminer, Tuta absoluta (Meyrick) in tomato fields in Egypt. Egypt J Agric. Res. 91(1):335-345

Leibee GL (1984) Influence of temperature on development and fecundity of Liriomyza trifolii (Burgess) (Diptera: Agromyzidae) on celery. Env. Ent. 13:497501

Mahmoud YA, Ebadah IMA, Abd-Elrazek AS, Abd-Elwahab TE, Masry SHD (2015) Population Fluctuation of Tomato Leaf Miner, Tuta absoluta (Meyrick) (Lepidoptera: Gelechiidae) During Winter and Summer Plantations in Egypt. RJPBCS 6:647-652

NomiKou M, Schraag AR, Sabelis MW (2004) Vulnerability of Bemisia tabaci immatures to phytosediid predators: consequences for oviposition and influence of alternative food. Ent. Exper. Appl. 110:95-103

Oliveira FA, daSilva DJH, Leite GLD, Jham GN, Picanco M (2009) Resistance of 57 greenhouse-grown accessions of Lycopersicon esculentum and three cultivars to Tuta absoluta (Meyrick). (Lepidoptera: Gelechiidae). Sci. Hort. 119:182-187

Rabei A (2014) Experimental design and statistical analysis of bio-experiments.

Tayeb ESH, Saad AE, Elbialy MA (2018) Insecticides and their mixtures for controlling Tuta absoluta infesting tomato under Egyptian field conditions. Alexandria sci. Exchange J. 39(2):215-222

Žnidarčič D, Trdan S, Zlatič E (2003) Impact of various growing methods on tomato (Lycopersicon esculentum Mill.) yield and sensory quality. Research Report, Biotechnical Faculty, University of Ljubljana 2: 341-348.

\section{Publisher's Note}

Springer Nature remains neutral with regard to jurisdictional claims in published maps and institutional affiliations. 